\title{
THE RELATIONSHIP BETWEEN TOURISM EXPERIENCE CO-CREATION, LIFE SATISFACTION AND BEHAVIOURAL INTENTIONS
}

\author{
Lončarić, D., Perišić Prodan, M., Bagarić, L.
}

This paper contributes to the debate about the relationships among tourism experience cocreation, satisfaction with vacation experience, satisfaction with the impact of vacation on overall life, life satisfaction and behavioral intentions. The main purpose of this paper is to point out the importance of tourist engagement in the co-creation of the vacation experience and the impact of satisfaction with that experience on life satisfaction and behavioral intentions. A survey was conducted on a convenience sample of 263 international tourists who visited several tourist destinations in Croatia. To test the proposed model, partial least squares structural equation modelling (PLS-SEM) was employed. It has been established that co-creation of tourism experience significantly contributes to the satisfaction of tourists staying in a destination, which has a positive effect on life satisfaction and future behavioral intentions.

Keywords: tourism experience co-creation, life satisfaction, behavioral intention JEL Classification: Z32, M31, L83, R11

\section{Introduction}

The purpose of this paper is to establish the relationships among degree of co-creation, satisfaction with vacation experience, satisfaction with the impact of vacation on overall life, life satisfaction and behavioral intention towards the visited tourist destination.

Co-creating value in tourism refers to the participation of tourists in tourist experience cocreation. Experience is a vital component of any tourist travel and results from the consumption of tourism products. Because of tourism's mostly service-related and intangible character, products/services in tourism are always experiential (Williams, 2006), and the visiting stage of tourists in a destination is the stage with the greatest potential for creating tourist experience and generating value for tourists (Neuhofer et al., 2012). Tourist experience co-creation implies experiences that are actively designed through the cooperation of tourists and companies. By intensifying their cooperation, a higher level of interaction and consumer-orientation can be reached as well as a higher level of created value (Neuhofer et al., 2013). Experience co-creation contributes to the authenticity and uniqueness of a destination (Binkhorst \& Den Dekker, 2009). Previous research shows that 
tourism experience co-creation in a destination affects satisfaction with the tourism experience (Prebensen et al., 2015). Numerous other studies have also confirmed the role of tourism in improving the quality of life of tourists (Kim et al., 2015; Moscardo, 2009; Neal et al., 2007). Furthermore, Mathis et al. (2016) found that experience co-creation has a positive influence on travel experience and loyalty to a service provider, and that travel satisfaction has a positive impact on overall satisfaction with life. There has, however, been little empirical research regarding the relationship between tourism experience value cocreation at the destination level, tourists' travel satisfaction and overall satisfaction with life, and tourists' behavioral intentions reflected in their loyalty to a destination. Hence, this study represents a contribution to the discourse on the correlations between the above-mentioned concepts.

The paper is organized as follows. First, we present the theoretical framework underpinning our study. Then, we develop a conceptual model and formulate research hypotheses based on the reviewed literature. The next section lays out the methodology and is followed by results of the research. In the last part the results, the limitations of the study, and suggestions for future research are discussed.

\section{Theoretical Framework}

The following section is an overview of the literature dealing with the concepts of tourism experience co-creation, tourist satisfaction, behavioral intention and life satisfaction.

\subsection{The concept of tourism experience co-creation}

The experience of leisure and tourism is considered as "a subjective mental state felt by participants" (Otto \& Ritchie, 1996, p. 166). It is achieved through active engagement with and participation in the given context of tourism settings, as well as through the emotional senses of touch and affect (Park \& Santos, 2016). Many factors influence the tourist experience. Da Costa Mendes et al. (2010) argue that the combination of inherent factors and associated satisfaction, in terms of acquired and consumed services during the holistic tourism experience, determine the overall satisfaction level of tourists.

According to Campos et al. (2016), there are two main approaches to tourism experience cocreation: first, as a process of interrelated interactions and activities between tourists and others, and second as a particular tourism experience as enacted in situ. In the first approach, experiences are the context in which this process occurs (before, during and after vacation) and provides value for tourists. In the second approach tourists actively interact with others during the consumption experience. This enables tourists to actively construct their own (consumption) experiences through personalized interaction, in the experience environment.

From the business point of view, co-creation involves considering tourist as a participant in design, production and consumption of experience or to collaborate in the creation of new products and services (Campos et al., 2016). From a tourist point of view, co-creation occurs 
in the tourist sphere where they are involved emotionally, physically, intellectually and spiritually to create value for themselves (Mossberg, 2007). By cooperating with service providers, consumers, i.e. tourists co-create their own experiences. Hence, "co-creation of experiences is about the process through which customers interact with service providers, or settings, to create their own unique experience"(Mathis et al., 2016). The essence of this interaction depends on the degree of tourist's involvement in this process. Therefore, customer experience is the focal point of such interactions and the result manifests in increased value for tourists.

\subsection{Tourist satisfaction and behavioral intentions}

Customer satisfaction is one of the most research topics in the field of marketing. Nevertheless, there is no single definition of this concept. Giese and Cote (2002) highlight three general components that can be identified: 1) consumer satisfaction is a response (emotional or cognitive); 2) the response pertains to a particular focus (expectations, product, consumption experience, etc.); and 3) the response occurs at a particular time (after consumption, after choice, based on accumulated experience, etc.).

Customer satisfaction is usually defined as the result of a cognitive process described by the disconfirmation of expectations theory (Bearden \& Teel, 1983; Churchill \& Surprenant, 1982; Oliver, 1980). It is a post-consumption evaluative judgment concerning a specific product or service (Gundersen et al., 1996). According to Oliver (1980, p. 13), satisfaction is "the customer's fulfilment response. It is a judgment that a product/ service feature, or the product or service itself, provided (or is providing) a pleasurable level of consumptionrelated fulfilment including levels of under- or over-fulfilment." Zeithaml and Bitner (2003) define customer satisfaction as the customer's evaluation of a product or service in terms of whether that product or service has met their needs and expectations. Customer satisfaction can be viewed as the result of particular transactions or cumulatively, as a result of previous transactions that the customer had with a particular company.

There is a connection between customer satisfaction and behavioral intentions. According to Gilmore (2003, p. 44) "positive behavioral intentions can include: saying positive things about a company and/or its service, spending more money with the company, remaining loyal and paying a price premium". Contrary, negative behavioral intentions include doing opposite and making negative comments about a company to outside companies such as consumer rights bodies, as well as to potential customers. Chan et al. (2015) note that there are two types of behavioral intention: short-term consequences (word of mouth, complaining and complimenting, recommendations) and long-term consequences (loyalty). In the tourism context, satisfaction can be considered "as a function of pre-travel expectations and post-travel experiences" (Chen \& Chen, 2010, p. 30). As an "individual's cognitive-affective state derived from a tourist experience" (del Bosque \& Martin 2008, p. 553) tourist satisfaction has been studied by marketing scholars in the psychological context. They agree 
that this concept is complex, encompassing not only cognitive and affective aspects but also physiological and psychological elements (Suhartanto et al., 2019).

The relationship between tourist satisfaction and behavioral intention has received a significant attention among researchers in hospitality and tourism. For example, various studies have proved that satisfied tourists are more likely to revisit a destination, recommended to others or express their positive comments (Baker \& Crompton, 2000; Chan \& Chan 2010; Ali et al., 2016; Williams \& Soutar, 2009).

\subsection{Life satisfaction}

Life satisfaction is often seen as a synonym to well-being, quality of life and happiness, but those concepts differ. Life satisfaction is understood as "the degree to which a person positively evaluates the overall quality of his/her life as a whole" (Veenhoven, 1996, p. 6). It is part of the broader concept of subjective well-being, which includes life satisfaction as a cognitive component, along with positive and negative feelings as affective components. This involves judging the fulfilment of one's needs, goals and desires (Sirgy, 2012, p. 13). Well - being is also defined as "an individual's sense that his/her life overall is going well" (Moscardo, 2009, p. 162). Further, quality of life refers to "an individual's perception of their position in life in the context of the culture and value systems in which they live, and in relation to their goals, expectations, standards and concerns" (WHOQOL Group, 1995). Also, happiness can be understood as “overall enjoyment of one's life as a whole (Tsaur et al., 2013).

Previous research has addressed the relationship between vacation experience and life satisfaction. Tourism is considered beneficial for human's mental and physical health and one life domain contributing to life satisfaction (Chen et al., 2016b). The influence of vacationing, as a component of leisure time, has been investigated by many authors (Dolnicar et al., 2012; Genc, 2012; Sirgy et al., 2011). Also, previous studies have confirmed the role of tourism in improving the quality of life of tourists (Kim et al., 2015; Moscardo, 2009; Neal et al., 2007; Neal et al., 2004). It has been established that the vacation experience does not only increase individual happiness but significantly affects the quality of life, i.e. on overall life satisfaction. (Chen et al., 2016a, 2016b; Kim et al., 2015; Moscardo 2009; Neal et al., 2007; Prayag et al., 2017). Chen et al. (2016b) have proved that recovery experiences during a leisure trip influence perceived life satisfaction after the trip. Moreover, Chen et al. (2016a) have examined the relationship between vacation experience associated with psychological recovery and life satisfaction through mediating variables of tourist satisfaction. They found out that vacation recovery experience has a direct effect on life satisfaction as well as an indirect effect on life satisfaction through tourism satisfaction. We can conclude that vacation experience is an essential form of leisure time that has an impact on quality of life and life satisfaction. 


\section{Hypotheses Development and Model Specification}

In the following section, relationships among the main concepts of this study are hypothesized, and a conceptual model is developed. In recent studies, it has been proved that tourist experience co-creation positively affects satisfaction with the vacation experience (Mathis, 2013). Moreover, the level of involvement and engagement in the co-creation experience intensifies the level of satisfaction with vacation experience (Prebensen et al. 2015). Therefore, we propose that:

H1: The degree of co-creation is positively related to satisfaction with a vacation experience.

Tourism experience represents a form of leisure time. Many scientists have explored and proved the impact of leisure time on subjective well-being or life satisfaction (Carneiro \& Eusébio, 2012; Neal et al., 1999). A large number of authors have also studied the effect of vacation as a component of leisure time (Dolnicar et al., 2013; Sirgy at al., 2011). For instance, Mathis et al. (2016) found that satisfaction with vacation experience is a significant predictor of satisfaction with the impact of the vacation on overall life. Further, a study by Kim et al. (2015) found that satisfaction with travel experience has a positive influence on the overall quality of life. Hence, we posit that:

H2: Satisfaction with vacation experience is positively related to satisfaction with the impact of vacation on overall life.

Neal et al. (2004) revealed that satisfaction with tourism services affects travelers' quality of life through the mediating effects of satisfaction with travel/tourism experiences and satisfaction with leisure life. Starting from the fact that tourism experience co-creation contributes to satisfaction with vacation experience (Mathis et al., 2016) we propose that:

H3: The degree of co-creation is positively related to satisfaction with the impact of vacation on overall life.

Further, scientist proved that tourist satisfaction is a determinant of destination loyalty. Thus, Da Costa Mendes et al. (2010) revealed that satisfaction positively affects tourist loyalty intention measured by revisit intention and willingness to recommend. Also, Kim et al. (2015) found out that satisfaction with travel experience has a positive influence on revisit intention. Therefore, we propose that:

H4: Satisfaction with vacation experience is positively related to behavioral intention.

Further, Kim et al. (2015) in their study show that leisure life satisfaction, as an evaluation of a specific sub-life domain, is a significant predictor of revisit intention. Therefore, we posit that: 
H5: Satisfaction with the impact of vacation on overall life is positively related to behavioral intention.

Numerous studies have established the role of tourism in improving the quality of life of tourists ( Kim et al., 2015; Moscardo, 2009; Neal et al., 2007; Neal et al., 2004). For example, the study by Neal et al. (2007) confirms that tourism is an important aspect of leisure life, which is an important factor in overall life satisfaction. Therefore, we propose:

H6: Satisfaction with the impact of vacation on overall life is positively related to life satisfaction.

The presumed relationships form the model seen in Figure 1.

Figure 1 | The conceptual model of this study

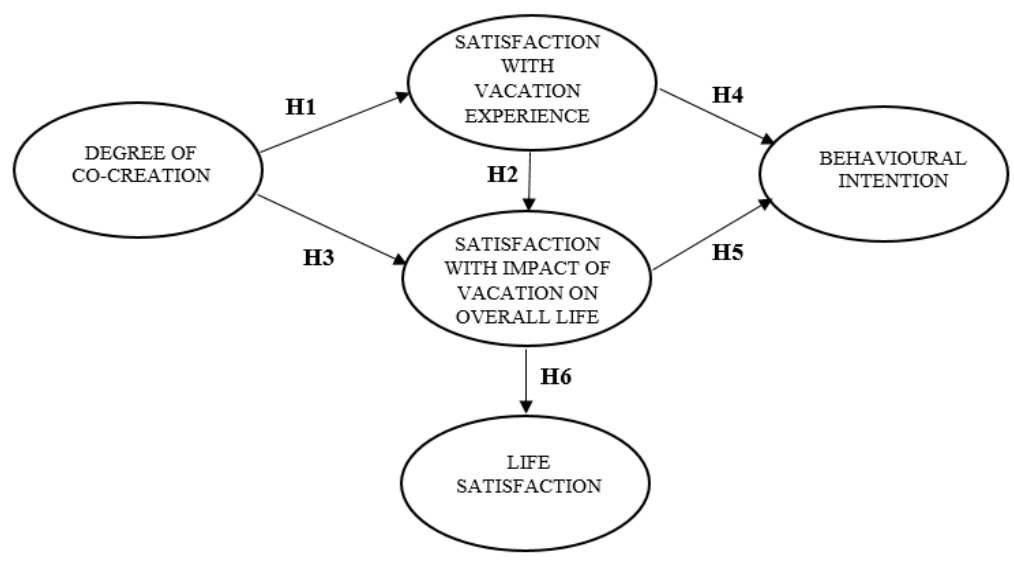

Source: authors

\section{Methodology}

The survey method was applied to collect data. Therefore, a questionnaire was designed. In addition to demographic questions and those concerning the behavior of tourists, the questionnaire included five constructs which were measured by items taken from the existing literature. The following constructs were involved: the degree of co-creation (Grissemann \& Stokburger-Sauer, 2012), satisfaction with vacation experience (Prebensen et al., 2015), satisfaction with impact of vacation on life overall (Mathis et al., 2016), satisfaction with life in general (Neal et al., 2007). Behavioral intention was measured by items that refer to revisiting a destination (Neal et al., 2007), intention to recommend (adapted from Kim et al., 2015), and sharing of experience (one item borrowed from Buonincontri et al., 2017). All items were measured on a five-point Likert-type scale ranging from "strongly disagree" to "strongly agree". The questionnaire was created in English and translated into Croatian, German and Italian. The research was conducted in summer 2017. 
The respondents were international tourists who visited several destinations in Croatia, in the broader Kvarner region. A total of 263 valid questionnaires were collected. Data processing and analysis applied univariate and multivariate statistical methods in SPSS 25 . The hypotheses are tested and confirmed using the partial least squares structural equation modelling (PLS-SEM). Results of the research are presented below.

\section{Findings}

Most respondents were female (58.2\%), between 26 and 35 years old (24.7\%), who came to the destination for the first time $(44.1 \%)$, with a partner $(34.2 \%)$, organized the trip individually (75.3\%) and stayed 4-7 nights (37.6\%) in private accommodation (42.6\%).

An evaluation of the hypothesized model started with verification of the measurement model. PLS-SEM results for the measurement model are presented in Table 1.

Table 1 | PLS results for the measurement model

\begin{tabular}{|c|c|c|c|c|}
\hline VARIABLE & ITEM & $\lambda^{*}$ & CR & AVE \\
\hline \multicolumn{5}{|c|}{ DEGREE OF CO-CREATION (COCR) } \\
\hline $\operatorname{cocr} 1$ & $\begin{array}{l}\text { I have been actively involved in the packaging of my } \\
\text { trip. }\end{array}$ & 0.880 & \multirow[t]{4}{*}{0.912} & \multirow[t]{4}{*}{0.721} \\
\hline cocr2 & $\begin{array}{l}\text { I have used my experience from previous trips in order } \\
\text { to arrange this trip. }\end{array}$ & 0.874 & & \\
\hline cocr3 & $\begin{array}{l}\text { The ideas of how to arrange this trip were } \\
\text { predominantly suggested by myself. }\end{array}$ & 0.881 & & \\
\hline cocr4 & $\begin{array}{l}\text { I have spent a considerable amount of time arranging } \\
\text { this trip. }\end{array}$ & 0.756 & & \\
\hline \multicolumn{5}{|c|}{ SATISFACTION WITH VACATION EXPERIENCE (SVE) } \\
\hline sve1 & $\begin{array}{l}\text { I am satisfied with the decision to participate in this } \\
\text { experience. }\end{array}$ & 0.722 & \multirow[t]{6}{*}{0.903} & \multirow[t]{6}{*}{0.609} \\
\hline sve2 & It was a wise choice. & 0.791 & & \\
\hline sve3 & It has been a good experience. & 0.803 & & \\
\hline sve4 & $\begin{array}{l}\text { I will participate in similar types of experiences in the } \\
\text { future. }\end{array}$ & 0.790 & & \\
\hline sve5 & I will recommend this experience to others. & 0.798 & & \\
\hline sve6 & I enjoy discussing this type of holiday with my friends. & 0.775 & & \\
\hline \multicolumn{5}{|c|}{ SATISFACTION WITH IMPACT OF VACATION ON OVERALL LIFE (SVOL) } \\
\hline svlo1 & $\begin{array}{l}\text { All in all, I feel that this vacation has enriched my life. } \\
\text { I'm really glad I went on this trip. }\end{array}$ & 0.819 & \multirow[t]{2}{*}{0.929} & \multirow[t]{2}{*}{0.686} \\
\hline svlo2 & $\begin{array}{l}\text { On this trip, I accomplished the purpose of the } \\
\text { vacation. This experience has enriched me in some } \\
\text { ways. }\end{array}$ & 0.842 & & \\
\hline
\end{tabular}




\begin{tabular}{|c|c|c|c|c|}
\hline svlo3 & $\begin{array}{l}\text { This vacation was rewarding to me in many ways, I feel } \\
\text { much better about things and myself after this trip. }\end{array}$ & 0.844 & & \\
\hline svlo4 & $\begin{array}{l}\text { Overall, my experience with this vacation was } \\
\text { memorable having enriched my quality of life. }\end{array}$ & 0.839 & & \\
\hline svlo5 & $\begin{array}{l}\text { My satisfaction with life in general was increased } \\
\text { shortly after this vacation. }\end{array}$ & 0.813 & & \\
\hline svlo6 & Overall, I felt happy upon my return from this vacation. & 0.809 & & \\
\hline \multicolumn{5}{|c|}{ LIFE SATISFACTION (LS) } \\
\hline sqol1 & I am generally happy with my life. & 0.914 & \multirow[t]{3}{*}{0.929} & \multirow[t]{3}{*}{0.813} \\
\hline sqol2 & $\begin{array}{l}\text { Although I have my ups and downs, in general, I feel } \\
\text { good about my life. }\end{array}$ & 0.913 & & \\
\hline sqol3 & I lead a meaningful and fulfilling life. & 0.878 & & \\
\hline \multicolumn{5}{|c|}{ BEHAVIOURAL INTENTION (BI) } \\
\hline rev1 & Revisiting the destination would be worthwhile. & 0.808 & \multirow[t]{7}{*}{0.930} & \multirow[t]{7}{*}{0.655} \\
\hline rev2 & I will revisit the destination. & 0.795 & & \\
\hline rev3 & I would like to stay more days in the destination. & 0.755 & & \\
\hline shex2 & $\begin{array}{l}\text { I will tell others about the tourism experience I have } \\
\text { had during this trip. }\end{array}$ & 0.779 & & \\
\hline rec1 & $\begin{array}{l}\text { I would like to recommend others to visit the } \\
\text { destination. }\end{array}$ & 0.854 & & \\
\hline rec2 & $\begin{array}{l}\text { I would say positive things about this summer } \\
\text { destination to others }\end{array}$ & 0.832 & & \\
\hline rec3 & $\begin{array}{l}\text { If someone is looking for a good summer destination, I } \\
\text { will suggest to him/her to patronize this destination. }\end{array}$ & 0.836 & & \\
\hline
\end{tabular}

${ }^{*}$ All factor loadings were significant at $p<.001$, CR stands for composite reliability; AVE stands for average variance extracted

Table 2 shows that all item loadings of the reflective constructs exceed the recommended value of 0.708 (Hair et al., 2014, p. 103). The composite reliability values, ranging from 0.903 to 0.930 , demonstrate that all five constructs have high levels of internal consistency reliability. Convergent validity assessment is based on the average variances extracted (AVE). The AVE values of all five constructs reflect the overall amount of variance in the indicators accounted for by the latent construct. All values are well above the cut-off of 0.50 (Hair et al., 2014), indicating convergent validity for all constructs.

Discriminant validity was assessed using the Fornell-Larcker criterion (Table 2).

Table 2 | Discriminant validity

\begin{tabular}{|l|r|l|l|l|l|}
\hline CONSTRUCT & COCR & SVE & SVLO & LS & BI \\
\hline Degree of co-creation (COCR) & 0.849 & & & & \\
\hline Satisfaction with vacation experience (SVE) & 0.476 & $\mathbf{0 . 7 8 0}$ & & & \\
\hline
\end{tabular}




\begin{tabular}{|l|r|r|r|r|r|}
\hline $\begin{array}{l}\text { Satisfaction with impact of vacation on } \\
\text { overall life (SVOL) }\end{array}$ & 0.501 & 0.688 & $\mathbf{0 . 8 2 8}$ & & \\
\hline Life satisfaction (LS) & 0.305 & 0.492 & 0.462 & $\mathbf{0 . 9 0 2}$ & \\
\hline Behavioral intention (BI) & 0.478 & 0.722 & 0.660 & 0.376 & $\mathbf{0 . 8 0 9}$ \\
\hline
\end{tabular}

The square roots of AVE values for all constructs are above the construct's highest correlation with other latent variables in the model. Hence, the results confirm the discriminant validity of the measurement model.

Table 3 presents the standardized path coefficient estimates, their respective t-values and pvalues, and summarizes the results of hypotheses testing.

Table 3 | Significance testing of the structural model path coefficients

\begin{tabular}{|l|r|r|r|l|}
\hline Path & \multicolumn{1}{|l|}{$\begin{array}{l}\text { Path } \\
\text { coefficients }\end{array}$} & \multicolumn{1}{l|}{ t- values } & p-values & Hypothesis \\
\hline COOCR $\rightarrow$ SVE & 0.476 & 7.514 & 0.000 & $\mathrm{H}_{1}:$ supported \\
\hline SVE $\rightarrow$ SVOL & 0.309 & 10.801 & 0.000 & $\mathrm{H}_{2}$ supported \\
\hline COCR $\rightarrow$ SVOL & 0.224 & 3.635 & 0.000 & $\mathrm{H}_{3}:$ supported \\
\hline SVE $\rightarrow$ BI & 0.510 & 5.495 & 0.000 & $\mathrm{H}_{4}$ : supported \\
\hline SVOL $\rightarrow$ BI & 0.309 & 3.663 & 0.000 & $\mathrm{H}_{5}:$ supported \\
\hline SVOL $\rightarrow$ LS & 0.462 & 7.998 & 0.000 & $\mathrm{H}_{6}:$ supported \\
\hline
\end{tabular}

It is evident that all relationships are statistically significant, thus supporting all six hypotheses. The $\mathrm{R}^{2}$ value obtained for satisfaction with vacation experience $(0.226)$ and satisfaction with life in general $(0.213)$ is weak while the $\mathrm{R}^{2}$ value for satisfaction with the impact of vacation on overall life (0.513) and behavioral intention $(0.572)$ can be considered moderate.

\section{Discussion}

The study confirms the positive effects that the vacation experience and the satisfaction of tourists with their stay in a destination have on satisfaction with life and on future behavioral intentions. The tourism experience is more memorable when tourists take part in co-creating their own experiences, a finding also confirmed by the research of Prebensen et al. (2015). Namely, this study confirms the relationship between satisfaction with the vacation experience and overall quality of life, which is in line with the findings of Kim et al. (2015) and Mathis et al. (2016). Furthermore, satisfaction with the vacation experience has a positive influence on future behavioral intentions, reflected in revisit intention, sharing experiences and recommendation, as also confirmed by Kim et al. (2015). The study further 
proves that satisfaction with the impact of vacation on overall life has a positive effect on life satisfaction, a finding consistent with that of Neal et al. (2007).

This study has certain limitations. They refer primarily to the sample and research instrument. The research was conducted on a convenience sample and encompasses a relatively small amount of tourist. Respondents were tourists who stayed in several destinations in only one region in Croatia. Further, the degree of co-creation was measured using four items which are related to arranging the trip, while other activities in the destination were not the subject of research. These limitations should be taken into account when interpreting the results of the study.

\section{Conclusion}

The research concludes that the co-creation of tourism experience has a positive impact on tourist satisfaction, the satisfaction with life and behavioural intentions. These results represent a small contribution to the theory and practice. The above findings present a starting point for making marketing decisions and developing marketing strategies in the tourism destinations. For tourists to gain an unforgettable tourism experience, they should be enabled to co-create experiences, take part in various activities, and share their tourism experience using information technology. The marketing managers in the destinations can contribute towards the creation of memorable tourism experiences for tourists by undertaking adequate marketing activities, such as the organization of special events, and by holding training programs for employees and residents. The involvement and engagement of tourists in co-creation their experience will enhance their life satisfaction, but also their loyalty to a destination. Further, the positive word-of-mouth can strengthen the image of the destination which is important in the contemporary global tourism market.

The results of this study should be seen as a platform for similar research in the field of tourist behavior, marketing and quality of life. Future studies should include a larger number of tourists and encompass a wider spatial area. Although the methodology used in this study was appropriate to its needs, other research methods and instruments should be applied in future studies to ensure that the effect of tourism experience co-creation on quality of life and future behavioral intentions can be studied in even greater depth.

\section{References}

Ali, F., Ryu, K., \& Hussain, K. (2016). Influence of experiences on memories, satisfaction and behavioral intentions: A study of creative tourism. Journal of Travel \& Tourism Marketing, 33(1), 85-100.

Baker, D. A., \& Crompton, J. L. (2000). Quality, satisfaction and behavioral intentions. Annals of tourism research, 27(3), 785-804.

Bearden, W. O., \& Teel, J. E. (1983). Selected determinants of customer satisfaction and complaint reports. Journal of Marketing Research, 20(1), 21-28. 
Binkhorst, E., \& Den Dekker, T. (2009). Agenda for Co-Creation Tourism Experience Research. Journal of Hospitality Marketing \& Management, 18(2-3), 311-327.

Buonincontri, P., Morvillo, A., Okumus, F., \& van Niekerk, M. (2017). Managing the experience co-creation process in tourism destinations: Empirical findings from Naples. Tourism Management, 62, 264-277.

Campos, A. C., Mendes, J., do Valle, P. O., \& Scott, N. (2016). Co-creation experiences: attention and memorability. Journal of Travel \& Tourism Marketing, 33(9), 13091336.

Carneiro, M., \& Eusébio, C. (2012). Segmentation of the tourism market using the impact of tourism on quality of life. Tourism \& Management Studies, 7, 91-100.

Chan, A., Hsu, C. H., \& Baum, T. (2015). The impact of tour service performance on tourist satisfaction and behavioral intentions: A study of Chinese tourists in Hong Kong. Journal of Travel \& Tourism Marketing, 32(1-2), 18-33.

Chen, C. F., \& Chen, F. S. (2010). Experience quality, perceived value, satisfaction and behavioral intentions for heritage tourists. Tourism management, 31(1), 29-35.

Chen, C. C., Huang, W. J., \& Petrick, J. F. (2016a). Holiday recovery experiences, tourism satisfaction and life satisfaction-Is there a relationship? Tourism Management, 53, 140-147.

Chen, C. C., Petrick, J. F., \& Shahvali, M. (2016b). Tourism experiences as a stress reliever: Examining the effects of tourism recovery experiences on life satisfaction. Journal of Travel Research, 55(2), 150-160.

Churchill, G.A. Jr, \&Surprenant, C. (1982). An investigation into the determinants of customer satisfaction. Journal of Marketing Research, 19(4), 491-504.

Da Costa Mendes, J., Do Valle, P. O., Guerreiro, M. M., \& Silva, J. A. (2010). The tourist experience: Exploring the relationship between tourist satisfaction and destination loyalty. Tourism, 58(2), 111-126.

Del Bosque, I. R., \& San Martín, H. (2008). Tourist satisfaction a cognitive-affective model. Annals of Tourism Research, 35(2), 551-573.

Dolnicar, S., Lazarevski, K., \& Yanamandram, V. (2013). Quality of life and tourism: A conceptual framework and novel segmentation base. Journal of Business Research, 66(6), 724-729.

Dolnicar, S., Yanamandram, V., \& Cliff, K. (2012). The contribution of vacations to quality of life. Annals of Tourism Research, 39(1), 59-83.

Genc, R. (2012). Subjective aspects of tourists' quality of life. In M. Uysal, R. Perdue, \& M.. J. Sirgy (Eds.), Handbook of tourism and quality-of-life research: Enhancing the lives of tourists and residents of host communities (pp. 149-167). Dordrecht: Springer.

Giese, J. L., \& Cote, J. A. (2002). Defining Consumer Satisfaction. Academy of Marketing Science Review, 1(1), 1-24.

Gilmore, A. (2003). Services, Marketing and Management. London: Sage Publications. 
Grissemann, U., \& Stokburger-Sauer, N. (2012). Customer co-creation of travel services: The role of company support and customer satisfaction with the co-creation performance. Tourism Management, 33(6), 1483-1492.

Gundersen, M. G., Heide, M., \& Olsson, U. H. (1996). Hotel Guest satisfaction among Business Travellers: What Are the Important Factors? The Cornell Hotel and Restaurant Administration Quarterly, 37(2), 72-81.

Hair, J. F., Hult, G. T. M., Ringle, C. M., \& Sarstedt, M. (2014). A Primer on Partial Least Squares Structural Equation Modeling (PLS-SEM). Los Angeles: Sage Publications.

Kim, H., Woo, E., \& Uysal, M. (2015). Tourism experience and quality of life among elderly tourists. Tourism Management, 46, 465-476.

Mathis, E. (2013). The Effects of Co-Creation and Satisfaction on Subjective Well-Being, Doctoral dissertation. Virginia Tech.

Mathis, E. F., Kim, H. L., Uysal, M., Sirgy, J. M., \& Prebensen, N. K. (2016). The effect of co-creation experience on outcome variable. Annals of Tourism Research, 57, 62-75. Moscardo, G. (2009). Tourism and quality of life: Towards a more critical approach. Tourism and Hospitality Research, 9(2), 159-170.

Mossberg, L. (2007). A marketing approach to the tourist experience. Scandinavian Journal of Hospitality and Tourism, 7(1), 59-74.

Neal, J. D., Sirgy, M. J., \& Uysal, M. (1999). The Role of Satisfaction with Leisure Travel/ Tourism Services and Experience in Satisfaction with Leisure Life and Overall Life. Journal of Business Research, 44(3), 153-163.

Neal, J. D., Sirgy, M. J., \& Uysal, M. (2004). Measuring the effect of tourism services on travelers' quality of life: Further validation. Social Indicators Research, 69(3), 243277.

Neal, J. D., Uysal, M., \& Sirgy, M. J. (2007). The Effect of Tourism Services on Travelers' Quality of Life. Journal of Travel Research, 46(2), 154-163.

Neuhofer, B., Buhalis, D., \& Ladkin, A. (2013). Experiences, co-creation and technology: a conceptual approach to enhance tourism experiences. In F. Joanna, \& M. Kevin (Eds.), Proceedings of the CAUTHE 2013: Tourism and Global Change: On the Edge of Something Big (p. 546). Christchurch, N. Z.: Lincoln University.

Neuhofer, B., Buhalis, D., \& Ladkin, A. (2012). Conceptualising technology enhanced destination experiences. Journal of Destination Marketing \& Management, 1(1-2), 36-46.

Oliver, R. L. (1980). A cognitive model of the antecedents and consequences of satisfaction decisions, Journal of Marketing Research, 17(4), 460-469.

Otto, J. E., \& Ritchie, J. R. B. (1996). The service experience in tourism. Tourism Management, 17(3), 165-174.

Park, S., \& Santos, C. A. (2016). Exploring the Tourist Experience. A Sequential Approach. Journal of Travel Research, 55(3), 16-27.

Prayag, G., Hosany, S., Muskat, B., \& Del Chiappa, G. (2017). Understanding the relationships between tourists' emotional experiences, perceived overall image, satisfaction, and intention to recommend. Journal of Travel Research, 56(1), 41-54. 
Prebensen, N. K., Kim, H., \& Uysal, M. (2016). Cocreation as moderator between the experience value and satisfaction relationship. Journal of Travel Research, 55(7), 934-945.

Sirgy, M. J., Kruger, S., Lee, D. J., \& Yu, G. B. (2011). How Does a Travel Trip Affect Tourists' Life Satisfaction? Journal of Travel Research, 50(3), 261-275.

Sirgy, M. J. (2012). The Psychology of Quality of Life: Hedonic Well-Being, Life Satisfaction, and Eudaimonia. Dordrecht: Springer.

Suhartanto, D., Brien, A., Primiana, I., Wibisono, N., \& Triyuni, N. N. (2019). Tourist loyalty in creative tourism: the role of experience quality, value, satisfaction, and motivation. Current Issues in Tourism, 1-13 (in press).

The WHOQOL Group, (1995). The World Health Organization Quality of Life assessment (WHOQOL): position paper from the World Health Organization. Social Science and Medicine, 41(10), 1403-1409.

Tsaur, S. H., Yen, C. H., \& Hsiao, S. L. (2013). Transcendent experience, flow and happiness for mountain climbers. International Journal of Tourism Research, 15(4), 360-374.

Veenhoven, R. (1996). The Study of Life Satisfaction. I W. E. Saris, R. Veenhoven, A. C. Scherpenzeel, \& B. Bunting B. (Eds), A comparative study of satisfaction with life in Europe (pp. 11-48). Eötvös University Press.

Williams, A. (2006). Tourism and Hospitality Marketing: Fantasy, Feeling and Fun. International Journal of Contemporary Hospitality Management, 18(6), 482-495.

Williams, P., \& Soutar, G. N. (2009). Value, satisfaction and behavioral intentions in an adventure tourism context. Annals of Tourism Research, 36(3), 413-438.

Zeithaml, V. A., \& Bitner, M. J. (2003). Services marketing: Integrated customer focus across the firm. New York, NY: McGraw-Hill.

\section{Authors}

\section{Dina Lončarić}

Department of Marketing

Faculty of Tourism and Hospitality Management

University of Rijeka

Primorska 42, 51410 Opatija, Croatia

dinal@fthm.hr

\section{Marina Perišić Prodan}

Department of Marketing

Faculty of Tourism and Hospitality Management

University of Rijeka

Primorska 42, 51410 Opatija, Croatia

marinap@fthm.hr

\section{Lidija Bagarić}

Department of Marketing 
Faculty of Tourism and Hospitality Management

University of Rijeka

Primorska 42, 51410 Opatija, Croatia

lidijab@fthm.hr 